UNIVERSITY OF CHITRAL JOURNAL OF LINGUISTICS AND LITERATURE

VOL. 5 | ISSUE I | JAN - JUNE | 2021

ISSN (E): 2663-1512, ISSN (P): 2617-3611

\title{
Marketing Class Consciousness in A Passage to India: A Marxist Analysis
}

\author{
Yasir khan \\ Assistant Professor, Government Graduate College Block No. 17 Dera Ghazi khan, Punjab, Pakistan. \\ Muhammad Farooq \\ Head Department of English, AIMS Layyah affiliated with Government College University Lahore. \\ Muhammad Ali \\ M.Phil Scholar, Institute of Southern Punjab, Multan, Punjab, Pakistan. \\ alinoorbzu@gmail.com
}

\begin{abstract}
The present paper is aimed to analyze the novel A Passage to India from the Marxist perspective. For the analysis the major theoretical insights have been taken from Marxist critics including Luckas (1968) and Antonio Gramci (1988). The analysis is thematic in nature. Generally, we see that Marxist criticism takes in consideration that the capitalist society is divided into haves and haves not. Lucaks (1968) considers that Marxist ideology can be extended from mere class conflicts to the class and caste system, gender, and race also. Therefore, this analysis has been extended from the simple Marxist category of class conflicts to the exploitation of the underdeveloped and developed, colonizer and the colonized, religion as well. Gramcian model Marxist criticism considers ideology as superstructure and state apparatuses as discursive tools of exploitation. In relation to Marxist critique, we see that the relationship of both bourgeoisie and proletariat classes is parallel to the colonizer and colonized in imperialist conditions. At present Marxist criticism also includes the slavery as an outcome of socio and economic un-equality. Marxist criticism counts religion as a marker of raising class consciousness. It has been found in the study that as the English people and administrative were the men of resources in India. The English had exploited the Indians on account of being without resources. In the conclusion, A Passage to India as a piece of literature represents the ideological and class-based relations based on economic relations.
\end{abstract}

Keywords: Marxist ideology, Class Conflict, Class Consciousness, Religion and Race

\section{Introduction}

E. M. Forster who is a renowned essay writer, literary, social critic, and novelist, has taken into consideration the very emotional deficiency of middle social English class and has 
vindicated its relation to other social classes in India using wit, symbolism, and irony as literary devices in major fictional works. He achieved a very significant reputation as a literary and historical critic with the publication of his large body of criticism and fiction i.e., novels - a passage to India is one of these distinguished novels. Although E.M Forster had started writing his novel A Passage to India in 1913, which was second year of his first visit to India. Foster completed his novel A Passage to India on his second visit to India in 1921, at that time he was performing his duties as secretary of Maharajahi of Dewas Stateii- the senior one in India. In this way a lot of mysterious aspects of the country i.e., India and his experiences in Dewas which was a foreign land for him. His visit to the Indian land basically contributed a lot to develop his dynamic vision which later provided strong material for writing of this novel. While in an interview Foster himself admitted this fact that it was really a great opportunity for me to serve in India and while at the same time it was the most daunting experience of my life. It provided me an experience which was diverse in nature and taste. For a writer like me the Indian land is full of mysteries and complex relations which are constructed around psychological ties (Forster, 1953, 8). Furthermore, his close friendship with Syed Ross Masood provided him a very rear opportunity to expand and enlarge his vision. By this close view of the Indian life, he was able to have a completely new view of the Indian civilization. So, due to these diverse ranging visions and experiences in Indian Territory, Foster developed interest for him for writing such a very distinguished novel. Moreover, we can say that India provided a very striking and mysterious background to E.M Forster because of which he was able to have had some sort of varied perspective of Indian civilization, the clash of different cultures, different synoptic modes of life, people with diverse temperaments and time-honored moral and social and religious values. All these were the things of fascination for the imagination of Foster.

Foster despite being an English man manages the experimentation of these values and culture of the orients as a sophisticated and visionary writer. He provides a very closely controlled, intelligent and an academic uniformity in the novel. McDowell (1982) contends that there is some sort of proficiency of craft, a solid plan of revealing class conflicts and a full expression of a compound visualization- the English and the Indians. The subtleness of the 
thought, a close examination of the consequences which result at the end, is an outstanding aura of empire in the Indian subcontinent.

\section{Literature Review}

Herz (2012) is of the view that what keeps A Passage to India repeatedly reveals the most appealing and charming motives is Foster's attempt to keep the Western values at an unharmed and safe state. He keeps on looking through these (western values). While at the same time he does not close his eyes from the non-western social and religious values. So, he simultaneously represents both sides without misunderstanding the one or the other. Marxist criticism considers the ideology as a superstructure which dominates the state apparatuses. So, we see that all the social relations basically the manifestation of economic ideological foundations.

\section{Class Consciousness as a Construct of Political Landscapes}

Although the novel A Passage to India is not any type of judicial understanding of the social and cultural values of India during the colonial rule of the British times yet it sensibly weighs the evidence on both British and Indian sides. So, we see that it has been taken two qualities of contradictory nature in it. The very first charge which is recounted against this novel is that it is some sort of archaic misrepresentation of British colonial perspective. Secondly, it is considered as misleading one. It has not properly represented Muslim canon of reality. At the same time this novel lacks Gandhi's perspective. (Herz, 1993)

As a result of the class consciousness the novel attempts to view the concepts of class on account of differential economic relation at the same time presenting the landscapes of spirituality by the symbols of mosques, caves, and temples. In this way he simultaneously maintains the impact of both Indian and western intellectual and philosophical quest of class, gender and race among the colonizers and colonized. For the analysis of the novel along with above mentioned constructs, not merely the Western values and intellectual quest but Indian perspective of philosophical inquiry has been presented from the Marxist perspective. This attempts to analyze and attacks the human troubles including race, poverty, age, gender, social alienation and ethnicity' (Wagner, 1994) 
UNIVERSITY OF CHITRAL JOURNAL OF LINGUISTICS AND LITERATURE

VOL. 5 | ISSUE I | JAN - JUNE | 2021

ISSN (E): 2663-1512, ISSN (P): 2617-3611

By intensifying our consideration of a broader outline of geographical and cultural landscapes, we might bring it parallel the Marxist point of criticism. For example, Marxist critics consider landscapes as some sort of expressions which reveals disproportionate social and economic interaction and relations in the umbrella of capitalism', (Till, 2004). In this way till (2004) associates the Marxist perspective with political landscapes of inequality as well. Therefore, all sort of landscapes including religious, cultural, and political nature are in conjunction in Marxist analysis. Another stance which has been developed by famous Marxist critics Nancy and James Duncan with the title post Structuralist Marxist lens of criticism take into consideration the landscapes as cultural texts which also communicate the political values and discourses. (Till, 2004).

Moreover, landscapes are considered as a parallel to the powers of the state (Cosgrove, 1992). There are also a lot of others who consider the national landscapes are founded on interests of the local elites as these landscapes aggravate the concept of nation. Furthermore, how do the people of some localities look themselves in relation to the other nations? (Olwig, 2002).

So, we see that landscapes define themselves as indicators of the prevailing social and cultural relations and political morals. In the same way, Foster's present novel takes the geographic and religious landscapes for example mosque, cave, and temple, all as some sort of wonderful natural outset of a given cultural context of a particular society. So, these exceptional cultural and religious landscapes evolve as representative of prevailing gender, race, class inequalities and spiritually constructed myths. Therefore because of these rational grounds, the novel A Passage to India can be taken from the perspective of cultural geography representing the concept of class consciousness inherently.

\section{Data Analysis}

Our major concern here is that in which perspective we take gender, class, and religion. On these ground, Marxist criticism fallouts in two distinguished approaches. Both religious and political approaches take into consideration the landscapes and view that how did these landscapes can create the political spaces of different nature at different scales ranging from the local to that of the global and world systems, the microcosmic category to the macrocosmic order. As a matter of fact, landscapes themselves act as an ingredient of multifaceted processes 
by which different individuals and the members of different groups may define themselves accordingly and can make their claims and challenges towards a particular political authority as well' (Nash, 1999). So, we see that the novel of the present study displays an imperialist version of civilization. It represents an ideological category which holds a central position in Marxist criticism. The dominant political ideology prevalent in the novel is that western political system is superior to the Indian political system. Same is the case of western culture. The western culture is superior to the Indian culture. The religion of the westerns is superior to the Indians.

\section{Race as Construct of Class Consciousness}

In relation to Marxist criticism the model of class and race is essentially taken in two different ways which includes the concept of cultural and geographical analysis as well. The first one i.e., culture is taken as an approach towards life which is predominantly an artifact of the Western culture. The western culture has been considered as a culture of superior and civilized people. And the cultural values of the orient culture have been considered as relatively inferior to the western culture. This concept is not new in the western culture rather it is profoundly set in the colonial past of the European ideological constructs. So, we see that Marxist ideology divide race into the categories of Western and Eastern cultures.

In this novel Forster consciously employs contradictory races in array to reveal the concepts of disparity, inequality, and misconception between two classes of different orientations. But in doing so to it, he overtly presents the characters from Hindu, Muslim, and the English as representatives of such miscellaneous classes. So, the different characters which Foster has taken for his novel are basically the representative of different races. So, the novel through these characters embalms a situation of class consciousness. These characters are respectively (1) Godbole, a very mild and a mystical professor at the Government College (2) Aziz, as a very volatile and perceptive physician in a job by the British Civil Surgeon; and a display of Indians ranged from many Anglo officials like Colonel Turton, Major Callendar, and Ronny Heaslop to some sort of a moderate humanist named as Cyril Fielding who is the Principal of Government College.

Moreover, the character of two other ladies of England has been included. The character of Adela Quested has been introduced to the real India from a feminist Marxist perspective. She 
wants to see what Ronny's is and Mrs. Moore's- Ronny's mother's- perspective of arrange marriage in India.

So, where the question of race is concerned Forster presents a critical view of Hindus, who comparatively abstain from publicly social as well as political discussions at large. However, Foster critically evaluates Hindus and finds them as the strong supporters and practitioners of caste system which is another form of class consciousness. Additionally, we see that the Muslims who hold a religious justification that all humans are the sons of Adam. There is no one preferred over the other. There is no superiority to the white over blacks and blacks over white. Consequently, all men are brothers from religious point of view are on bad terms with one another or dishonored by the other Muslims in the Indian context. The character of Aziz as the representative of Muslim in A Passage to India is divided psychologically in himself which is the representation of extending binary oppositions i.e., his mind is at the same time credulous and logical, insightful, and rational at once and political and nonpolitical for all the time. The character of Aziz is the representative of the Muslims in India who were in the state of chaos and disorder. However, the character of Aziz can be taken as an intermediary and bridging one between the West and the East as he tries to attempt a very critical role in abridging the tie of friendship between the Englishman (Fielding) and the Indian (Himself). But he could not build such as a bridge between two according to his own will. It is impossible for him to make a sense of the Western mind which he may perceive. Moving from the Hindus and Muslims to AngloIndians, it is worthy to notice that both the British and the Muslims do not respect the mysteries of India.

Ronny uses some agonizing expressions in front of his mother about India. Mrs. Moore says to Ronny that your sentiment is like that of a god. Even this extraction depicts to what degree the colonizers disrepute the religious beliefs of the local people and treat them as an "Other". Basically, this is what laid the basis of class conflict and the situation of class consciousness.

On political point, the writer like Forster felt more common with the political troubles of British India than that of any other colonized subjects. Indians' aspirations for the sake of 
independence appeal him directly while on the other grounds his personal democratic views are completely contradictory to opinions of British imperialism.

Forster provides a wide-ranging fact of the social as well as political situations of the British Raj in India. He interprets the things impartially as he never acts as completely a proBritish and never as completely a pro-Indian. He attempts to have a very wide-ranging picture of the twentieth century British Raj in India. Foster seems to find out the inequalities which the Indian people had to face from the British Raj in India. He stresses on the providence of social egalitarianism in Indian societal structures. He says that the Indian domain can be made more democratic by enduring and establishing some institutions on the base of social equality which may treat the both- the British and the Indians equally. But this pedestal of race proved as an element of failure because it was bound to be collapsed soon" (Das, 1977, 19-20).

So, the human race as a category of class consciousness is primarily divided among two distinguished and separate categories i.e., the colonizers and the colonized. Fanon (1963) contends his view as colonialism inherently is a product which divides this world into different discriminatory parts. In Indian context the society was divided into two classes' i.e., the colonizers and the colonized. Said (1978) in his seminal work is of the view that colonialism basically is all about to create the Europeanized stereotypical which may take the Orients as inferior and other in relation to the western world. Moreover, the west intrinsically is more tended to put down such people i.e., who is non-European. The Europeans also try to govern the others through the manipulative use of language and dissemination of knowledge. So, we see that the colonizers find themselves and the colonized ones on different social scales. Consequently, these colonized are scarcely treated equal the colonizers on equal human boards. Therefore, these colonized rapidly tend to be in the status of an object and treated as others (Memmi, 1974, 8586).

Likewise, Ronny considers the way the British takes Indians in capacity of some sort of insignificant issue. This situation leads Mrs. Moore into a state of disappointment. Later we see that he questions his mother- Mrs. Moore- by saying that what sort of a woman you are that you start worrying over unimportant issues. (51). For Mrs. Moore, his act of saying the Indians as an unimportant issue was really agonizing because her ideological conditioning had not been 
degraded by the colonization the English and their treatment as inhuman beings. In addition, in a futile effort Ronny tries to persuade Mrs. Moore about the fundamental presence of British in India. As, we had an idea that the ultimate agenda of the colonizers in India was to bring out the forefront the utter darkness of the colonized people' (Memmi, 1974).

This westernized version of reality lead to the status of class consciousness between the colonizers and the colonized. Colonialism basically provides a very site of contact, conflict, and a sense of compromise among different groups within a spatial background. Particularly, it provides some sort of contact in the region where different cultures can meet, make a situation of clash and struggle with one another, usually in a very high equal relations of dominance and subordination. However, the propositions of imperialism and colonialism mainly focus on practices such as dominance or power in the perspectives of the colonizer and the colonized. In the case of A Passage to India Foucault (1977) has rightly suggested that the construct of power is merely not a phenomenon of binary oppositions amid those who are dominant and powerless rather it is more an internalized sense, and it is transformed not only through material elements but also through discursive practices which construct a form of normative category of belonging i.e class, gender, and race. For example, Aziz on account of being an Indian is not permitted to enter Club of English people. This Club was more a demarking place of political landscapes which were defined by the inclusion of some people while the exclusion of the other. In Foster's A Passage to India, the idea of class and race includes the colonizers and the colonized, the black and the white.

If we consider this novel from the perspective of Marxist criticism, we see that Foster seems successful in depicting the real situation of class consciousness in Indian context. Lukacs holds the view that class consciousness is not merely a peculiar situation in the society, or slightly, it is only apparent a situation which is portrayed in this novel.

\section{Construct of Class as a Category of Exploitation}

From cultural perspective the concept of class refers to the status, an occupation of a group, or the lifestyle of the members of that group. It also includes the patterns of production and consumption without paying a significant concentration to the questions related to ontology. 
The constructs of class are more exploitative in nature. The structured relations that a class usually inherits are lived and experienced ones. So, the concept of class includes the aspects of identity as well which are more regional and historical variables (Duncan \& Legg, 2004, 253). The construct of Class takes into consideration the cultural and geographical aspects as well. In case of the novel a passage to India, India has been represented as a very mysterious locale where different classes are structured and have different aspects of identifications. Generally, the Marxist analysis takes into consideration, the rational and cultural values which are representative of the colonized and powerless in relation to the intellectual values adopted by the colonizers and economic Elites. This position formulates some sort of ordered (society divided into classes) universe. The nations which have resources have a different sort of intellectual values while those which are powerless have their own distinguished intellectual values. Consequently, such structural division of the society reveals the inequality among those who haves and those who haves not, those who are black and white and those who are civilized and those who are not cultured. For example, although Adela Quested and Mrs. Moore both are considerably of diverse interests from one another. Mainly their temperaments are different, yet both represents of the western values and thought process. So, we see that both strongly supporters some sort of divided universe. Mrs. Moore, as a representative of Christianity, strongly wishes to have a universe which is dominant by some sort of divine being. Her universe is mainly liable for the providence of justice to those who are Christians. Such a divine force is responsible for eventual reward of human deeds. Furthermore, Adela is very much skeptical like Fielding; in her fundamental religious viewpoint i.e she is very much interested in keeping her mind open towards her religious affairs. Although her skepticism remains dominant in the whole novel, yet she never confirms and never denies the existence of a deity. She keeps on believing that these fundamentals of the transcendent world are still sufficient to meet her spiritual demands.

In A Passage to India overtly it has been represented those colonizers in India have had some sort of a mission that was justified by Christianity. If we take into consideration the religion as a parallel to the class, the religion of the whites' i.e., Christianity has been represented superior to the other religions of India. For example, Ronny considers that we (the white people) 
are not the sons of the soil rather some foreigners for India but the sole purpose of our presence in India is to provide justice and maintain the situation of peace in India. Further, he says we are not enjoying our lives in India in its occupation rather we are in great difficult situation. He considers that Indian Territory is not like drawing room for them. About himself Ronny says that I am merely a government official. However, we (The English people) are not feeling well in India. Similarly, we- The English- also have no intention in our mind to feel pleasant in India. We are here on a mission. We are here to do something of great importance which is also divinely in nature. (pp. 51-52).

This passage clearly purports that the colonialists had some inherent objectives in their mind that these people are here on some divinely duty. While at the same time, these colonial masters wear some sort of masks to hide their identity as imperialist and occupiers. The real intentions of the colonizers are disguised under the shaded realities while on superficial level they are intended to bring knowledge and development to the most uncivilized Indians. These colonial masters also exhibit racial, political, and gendered biases for the colonized. Aziz reveals the real intention of the colonial masters and mentions what the white people had done for the Indians. 'Damn the English even at their best' (p. 169).

Let alone establishing a mutual friendship with each other, the colonized have always been intimidated with colonizers. India as depicted in this novel Forster himself seems antagonistic to colonizers and criticizes colonizers in their act of occupying foreign lands under imperialist impulse among such countries India is one. We see in the novel that although a lot of attempts had been made by the colonizers (The white English people) to cultivate and tame the wild and uncultured Indians, yet it remains a failure from the western perspective. As we see that the ultimate agenda of the English colonizers was to reshape India according the western intellectual and civilization which provided a missionary justification to the imperial power from Christian perspective, but all the efforts of the colonizers ended in dust' (234). Although the Indians demanded an absolute freedom from the colonizers in every field of life so that they may have a united and free India, yet Foster considers that India and the Indians will never be able to be a one and united nation. Fielding and Aziz both represent the long-lasting attitude of the Indians towards the phenomenon of colonization in India. For example, Aziz is very much 
hopeful for the establishment of a free and united nation. While on the other hand, Fielding is quite hopeless for the establishment of free and united India. So, we see that different persons as representative of different cultural and social backgrounds strengthen the constructs of racism, class, and religion. Thus, even an ordinary reader can take the novel A Passage to India as a document extending the prevailing conflicts of class consciousness in India.

\section{Religion as Infusing Opium- a Category of Exploitation}

As we know from the review of the Marxist criticism that religion has been considered a very important marker in the class division and exploitation as 'these [religions] hold a similar at position on human sense of curiosity' (Glacken, 1967: 35). According to Marxist perspective sacred places, in essence, are both locally and universally admitted, it cannot mere drive one to the other as divinely quest for power. It also drives someone from consciousness that the persona of God cannot be restricted around a solo locality (Lane, 1988, 15). Smith (1978) is of the view that such views lead to the state of distinguished orientations i.e., the first one in locative in nature and the second one is utopian in nature. Thus, very same representation can be traced in Foster's A Passage to India. The English as a class had been represented as a utopian class while on the other hand the Hindus and Muslims had been represented as local and savage people. In this way, the constructs of class consciousness have been evaded in the novel on account of religious differentiations.

As we might not hold a significant consent of the Christian outlook as a religion, yet still it seems very much improper to consider that only Christianity may talk of Buddhists, Muslims, Jewish and Hindus perspectives. As these religious doctrines hold many major as well minor groups which are also common among many other religions of India. So in A Passage to India the mosques, caves and temples stand for particular type of religious experiences and a line of spirituality. Speaking about the mosque by the character of Aziz, E.M Forster contends that 'Here is Islam and his country. Furthermore, there is a Faith. In the perspective of Forster, temples and caves represent also much more than religious orthodox values of Christianity. (Allen, 1955). Additionally, Foster basically craves the features in his novel which are emotional in nature and intellectual in capacity. It enables him to take into consideration religion by 
formulating his themes of the novel around the mosques, caves and temples. The affecting nature has been represented in the form of Aziz's opinion of life. Aziz's body and thinking is very much fond of his home. While on the other hand the rational faculty of Aziz's personality is evident "“There is no God but God, it is only a game with words, really a religious pun, not a religious truth" (307).

As the other objective of the present paper is the consideration of the philosophical practice of India, it is noteworthy to elucidate that Hinduism as well. It as a religion with followers more than one billion and as being third largest world religion after Islam and Christianity, includes in it many other various types of the sects, communities, ethnicities and classes like other religions of India. Traditionally, temples of Hindus are majorly the places of transcendence and divinity' (Michell, 1988). In this way E.M Foster incorporates all such elements which are considered as the symbol of good and evil in Hindu religion along with the essences of human life in India. Hindu's belief of rebirth (samara) determines the caste system as well. So, the course of rebirth which is named as reincarnation in Hindu mythology is without referential beginning and ending. The idea of One, Brahman as an Absolute Human Being finds expression in Hindu mythology as well. In this way one gets recognition with a broader Cosmo universal self i.e Brahman. Such kind of freedom is named as moksha. These major approaches take into consideration the problems of escaping and the endless cycles of life and death.

\section{Conclusion}

To conclude we can say that there is a noticeable class conflict on both theoretical and notional analysis to geography of belief and class consciousness which Marxist criticism suggests. Marxist critics consider that the economic inequality is an inherent structural pattern of capitalist societies. Similarly, cultural and geographical advance in the fictional texts Marxist perspective thus raising the category of class consciousness. Therefore, the major objective of this paper is to take into consideration the implication of spiritual landscape which reflects different modes of life and different circumstances of the people by taking into consideration the characters which are the representative of the colonizer and the colonized world.

So, this paper purports the idea of - race, gender, and class consciousness between the colonized and the colonizer. The Muslim and Mosque; Hindu and Temple, Anglo-Indian and 
Caves are implied here systematically to each other in order to show a hierarchy of godly sort. We see that the category of class conflicts is more extended to the exploitation of the underdeveloped and colonized, religion and race as well. In relation to Marxist critique the relationship of the bourgeoisie and proletariat is parallel to the colonizer and colonized. At present Marxist criticism also includes the slavery as an outcome of economic un-equality. It has been found in the study that as the English people and administrative were the men of resources in India, the exploited the Indians on account of being without resources. In the conclusion, A Passage to India as a piece of literature represents the ideological and class based relations on the basis of economic relations.

\section{References}

Allen, G. O. (1955). Structure, symbol, and theme in E.M Forster's A Passage to India. America's new world. Madison: University of Wisconsin Press.

Companion to Cultural Geography. USA: Blackwell Publishing.

Cosgrove, D. (1992).The Palladian landscape. Leicester: Leicester University Press.

Das, G. K. (1977). E.M. Forster's India. London: Macmillan.

Duncan, N.\& Legg, S. (2004). Social class. In J. S. Duncan, N. C. Johnson \& R. H. Schein Fanon, F. (1963). The wretched of the earth. Paris: Présence Africaine.

Forster, E. M. (1922). "Reflections in India 1: Too Late?" The Nation and the Athenaeum, 30, 614-15.

Foster.E.M(2002)A Passage to India: Rosetta Books: London. geographies. London \&New York: Arnold.

Foucault, M. (1977). Discipline and punish: The birth of the Prison. London: Allen Lane. (Eds.), A Companion to Cultural Geography. USA: Blackwell Publishing. al., (Eds.), Rereading Cultural Geography. Austin: University of Texas Press.

Glacken, C. J. (1967). Traces on the Rhodian shore. Berkeley: University of California Press.

Herz, J. S. (1993). A passage to India: nation and narration. USA: Twayne Publishers. history of religions. Leiden: E. J. Brill.

Lane, B. C. (1988). Landscapes of the sacred: Geography and narrative in American. USA: 
Leicester University Press.

Lukacs.G (1989) The Historical Novel: London Merlin Press.

McDowell, F. P. (1982). E.M. Forster. Boston: Twayne Publishers.

Memmi, A. (1974). The colonizer and the colonized. 1965. rpt. London: Souvenir Press.

Michell, G. (1988). The Hindu temple: An introduction to its meaning and forms. USA:

Nash, C. (1999). Landscapes. In P. Cloke, P. Crang, \& M. Goodwin (Eds.), Introducing human

Olwig, K. (2002). Landscape, nature, and the body politic: From Britain's Renaissance to Publications of the Modern Language Association of America, 70(5), 934-954.

Said, E. (1978). Orientalism. New York: Random House.

Smith, J. Z. (1978). The wobbling pivot. In J. Z. Smith (Ed.), Map is not territory: Studies in the

Till,K. E. (2004). Political Landscapes. In J. S. Duncan, N. C. Johnson \& R. H. Schein (Eds.), A University of Chicago Press.

Wagner, P. L. (1994). Foreword: culture and geography: thirty years of advance. In K. E. Footeet Linguistics \& Literature, Pakistan. This article is an open access article distributed under the terms and conditions of the Creative Commons Attribution (CC BY) (http://creativecommons.org/licenses/by/4.0/). 